\title{
EVALUASI PENGGUNAAN EKSTRAK LAMUN SEBAGAI BAHAN AKTIF ANTIFOULING TERHADAP PRODUSEN PERAIRAN
}

\author{
Rachma Puspitasari ${ }^{11}$ \\ 1) Pusat Penelitian Oseanografi - LIPI \\ Diterima tanggal: 15 Januari 2016; Diterima setelah perbaikan: 10 Februari 2016; Disetujui terbit tanggal 5 Maret 2016
}

\begin{abstract}
ABSTRAK
Penggunaan TBT sebagai cat antifouling telah dilarang di dunia, oleh karena itu diperlukan bahan alternatif yang dapat menggantikannya. Fase awal dari fouling adalah pembentukan biofilm yang melibatkan bakteri. Cymodocea serrulata dan Syringodium isoetifolium diketahui berpotensi antibakteri terhadap Vibrio harveyii dan Bacillus subtilis. Sebelum dikembangkan lebih jauh sebagai bahan aktif cat antifouling, perlu diteliti keamanan dari lamun tersebut terhadap produsen primer perairan, salah satunya Chaetoceros graclis. Ekstrak kedua jenis lamun tersebut dipaparkan terhadap diatom selama 96 jam pada kondisi laboratorium dan dianalisis pengaruhnya terhadap pertumbuhan fitoplankton. Ternyata, $\mathrm{S}$. isoetofolium menunjukkan penghambatan pertumbuhan diatom. Hasil dari uji anti bakteri dan bioassay menunjukkan bahwa lamun $C$. serrulata lebih potensial untuk dikembangkan sebagai bahan aktif cat antifouling daripada S. isoetifolium.
\end{abstract}

Kata kunci: diatomae, fouling, C. serrulata, S. isoetifolium

\begin{abstract}
The use of TBT as antifouling paints had been banned in the world, so it is necessary to develop alternative materials that can replace it. Initial phase of fouling is biofilm, involving bacteria. Cymodocea serrulata and Syringodium isoetifolium known had antibacterial activity against Vibrio harveyii and Bacillus subtilis. Before developed further as an active ingredient antifouling paint, they need to be examined about the security of the seagrass to aquatic primary producer, Chaetoceros gracilis. Extract from both seagrass were exposed to diatoms for 96-h and analyzed its influence to phytoplankton growth. Apparently, S. isoetofolium showed inhibition of growth of diatoms. Results of anti-bacterial and bioassay test showed that $C$. serrulata were more potential to be developed as an active ingredient antifouling paints than S. isoetifolium.
\end{abstract}

Keywords: diatom, fouling, C. serrulata, S. isoetifolium

\section{PENDAHULUAN}

Biofouling umum terjadi pada benda-benda yang sering mengalami kontak dengan air laut seperti bagian bawah kapal dan bangunan-bangunan yang terendam di bawah laut. Beberapa kerugian dari adanya organisme penempel ini adalah meningkatnya konsumsi bahan bakar yang akan berdampak pada meningkatnya polusi karbondioksida dan polusi udara lainnya, meningkatnya beban kerja mesin untuk mempertahankan kecepatan, meningkatnya pembersihan dock dalam keadaan kering dan meningkatnya biaya perawatan ketika kapal tidak beroperasi, hilangnya kemampuan manuver (maneuverability) dari kapal, serta meningkatnya resiko kontaminan ekologis dari spesies asing (Bellas, 2006). Oleh karena itu, penggunaan cat antifouling banyak digunakan dalam industri perkapalan. Dahulu, cat antifouling berbahan dasar tributiltin (TBT) banyak digunakan pada pertengahan 1960an karena terbukti sangat efektif untuk menanggulangi organisme target penyebab fouling. Lebih dari 30 tahun, senyawa organotin ini digunakan sebagai senyawa antifoulant hampir di 70\% dunia pelayaran (Bellas, 2006). Namun kemudian, ditemukan efek lingkungan berupa toksisitas akut yang disebabkan oleh TBT pada organisme nontarget dan akhirnya TBT dilarang digunakan di berbagai negara. Menurut Wang et al. (2008), penelitian mengenai efek TBT pada tiram dan kerang-kerangan pada konsentrasi nanomol yang rendah telah dilakukan. TBT mengganggu sistem endokrin di sejumlah kerang laut yang mengakibatkan perkembangan karakteristik organ kelamin jantan pada siput laut betina. TBT juga menyebabkan gangguan sistem imun pada organisme membentuk perubahan formasi (malformation) cangkang setelah pelepasan TBT pada level yang sangat rendah di air (Sudaryanto, 2001). Pada November 1999, International Maritime Organization mengeluarkan resolusi mengenai pembatasan penggunaan cat berbahan dasar TBT pada kapal yang berlaku sejak Januari 2003, sedangkan pelarangan diberlakukan penuh sejak Januari 2008 (IMO RESOLUTION A. 895 21, 25/11/1999 dalam Bellas, 2006). Sejak pelarangan penggunaan cat berbahan dasar TBT, penggunaan biosida alternatif pengganti meningkat karena dianggap aman secara ekologis dan memiliki nilai ekonomis yang tinggi. Hal yang perlu diperhatikan 
adalah bagaimana efek ekologis dari biosida-biosida tersebut pada ekosistem akuatik, baik pada organisme target maupun pada organisme nontarget.

Di dalam lingkungan laut, semua permukaan benda bawah air dipengaruhi oleh penempelan organisme fouling seperti bakteri, alga dan invertebrata khususnya remis dan teritip. Biofilm merupakan sekelompok sel yang dihasilkan oleh bakteri tertentu yang bersifat irreversible dan menutupi permukaan dengan bahan utamanya berupa polisakarida. Bakteri laut diduga turut menyebabkan terjadinya fouling. Menurut Zobell \& Allen dalam Sidharta (2000), bakteri berperan dalam terjadinya fouling dengan cara: 1. memberikan tempat perlekatan untuk larva planktonik berbagai organisme fouling, 2. menyuramkan permukaan benda-benda yang cerah dan terang, 3 . menyediakan sumber makanan bagi teritip, tiram, tunicate dan lainnya, 4. menyediakan pengendapan bahan-bahan berkapur bagi oganisme sesil, dan 5 . Meningkatkan kandungan $\mathrm{CO}_{2}$ dan amonia yang dibutuhkan tumbuhan laut.

Arlyza (2008) melaporkan bahwa ada delapan jenis lamun yang menunjukkan aktifitas sebagai antibakteri. Jenis lamun yang paling berpotensi sebagai antibakteri secara berurutan diantaranya adalah Thalassia hemprichii, Halodule pinnifolia, Syringodium isoetifolium, Cymodocea serrulata dan Cymodocea rotundata. Bila potensi ekstrak lamun ini dapat dikembangkan tentu akan membawa manfaat ekonomi dan aman bagi lingkungan.

Untuk membuktikan bahwa ekstrak lamun ini aman bagi lingkungan khususnya produsen perairan yaitu mikroalga, perlu dilakukan penelitian untuk mempelajari efek dari biosida alami berbahan dasar ekstrak lamun terhadap pertumbuhan mikroalga. Mikroalga adalah komponen esensial dari ekosistem akuatik yang memproduksi oksigen dan substansi organik melalui proses fotosintesis yang sangat dibutuhkan bagi organisme lainnya seperti ikan dan invertebrata. Mikroalga berperan penting dalam keseimbangan ekosistem akuatik karena berada di tingkat pertama dalam rantai makanan yang memproduksi bahan organik dan oksigen melalui fotosintesis (Berard, 1996).

Pada penelitian ini digunakan mikroalga Diatomae, Chaetoceros gracilis. Diatom planktonik $C$. gracilis adalah spesies yang dapat digunakan sebagai biota uji dalam bioassay karena memenuhi beberapa persyaratan sebagai biota uji yaitu pertumbuhannya yang cepat, sensitivitas dan penanganannya mudah di laboratorium (Hindarti, 2008). Chaetoceros gracilis merupakan spesies dari kelas Bacillariophyceae dan merupakan salah satu genus diatom penting dalam plankton laut karena merupakan genus terbesar dan berperan sebagai produsen primer serta merupakan makanan penting bagi biota lain terutama udang (Panggabean, 1997). Dalam uji toksisitas, beberapa parameter yang umum dilihat untuk memperkirakan efek dari toksikan terhadap mikroalga antara lain pertumbuhan dan aktivitas fotosintetik (Campanella et al., 2000).

Tujuan khusus dari penelitian ini adalah membandingkan keamanan dari ekstrak dari dua jenis lamun yang berbeda yaitu C. serrulata dan $S$. isoetifolium terhadap mikroalga $C$. gracilis. Pemilihan kedua jenis lamun ini berdasarkan pada ketersediaan lamun di lokasi penelitian karena tidak semua jenis lamun dapat ditemui di lokasi dan mempertimbangkan faktor kecukupan lamun untuk memenuhi berat ekstrak. Informasi dari penelitian ini bermanfaat untuk mengkaji resiko keamanan penggunaan senyawa biosida berbahan dasar ekstrak lamun terhadap mikroalga, $C$. gracilis.

\section{METODE PENELITIAN}

\section{Larutan uji}

Larutan uji yang digunakan diperoleh dari ekstrak lamun yaitu Cymodocea serrulata dan Syringodium isoetifolium. Ekstrak diperoleh dari maserasi lamun segar selama 24 jam dalam pelarut polar metanol pekat dengan menggunakan magnetic stirrer pada kecepatan konstan. Setelah itu, ekstrak disaring dan filtratnya dievaporasi pada suhu di bawah titik didih pelarut organik $\left(40-50^{\circ} \mathrm{C}\right)$. Ekstrak lamun C. serrulata dalam metanol menunjukkan aktivitas antibakteri yang kuat terhadap Vibrio harveyii dan Bacillus subtilis sedangkan $S$. isoetifolium terhadap $B$. subtilis saja (Arlyza, 2008). Tiap ekstrak dibuat larutan stok konsentrasi $10.000 \mathrm{ppb}(0,01 \mathrm{~g}$ ekstrak dalam $1 \mathrm{~L}$ akuades) dengan menambahkan 0,5 ml metanol kemudian ditambah akuades hingga $1 \mathrm{~L}$. Larutan stok kemudian diencerkan dengan air laut saring 0,45 $\mu \mathrm{m}$ untuk mendapatkan konsentrasi larutan uji yang diinginkan. Setiap 1 liter air laut saring ditambahkan 1 $\mathrm{mL}$ media Walne non EDTA. Komposisi media Walne dapat dilihat dalam Tabel 1.

Setelah larutan stok siap, larutan stok diletakkan di tempat gelap dan pada suhu kamar untuk menghindari fotodegradasi. Konsentrasi yang dipakai adalah kontrol negatif dan seri konsentrasi uji yaitu 1 , 10, 100 dan 1000 ppb ekstrak senyawa uji. Tiap konsentrasi dibuat tiga ulangan dan diletakkan secara acak di rak perlakuan.

Secara umum, kondisi pengujian ini mengacu pada CPMS-II, 1995 seperti yang tercantum dalam Tabel 2. 
Tabel 1.

Komposisi bahan-bahan media Walne bagi pemeliharaan C. gracilis (CPMS II, 1995)

\begin{tabular}{lll}
\hline Komponen & Komposisi & $\begin{array}{l}\text { Jumlah terlarut } \\
\text { dalam } 100 \mathrm{~mL} \text { akuades }\end{array}$ \\
\hline & $\mathrm{NaNO}_{3}$ & $10,0 \mathrm{~g}$ \\
& $\mathrm{Na}_{2} \mathrm{EDTA}^{2}$ & $4,5 \mathrm{~g}$ \\
& $\mathrm{H}_{3} \mathrm{BO}_{3}$ & $3,36 \mathrm{~g}$ \\
Stok 1 & $\mathrm{NaH}_{2} \mathrm{PO}_{4} \cdot \mathrm{H}_{2} \mathrm{O}$ & $2,0 \mathrm{~g}$ \\
& $\mathrm{FeCl}_{3} \cdot 6 \mathrm{H}_{2} \mathrm{O}$ & $0,13 \mathrm{~g}$ \\
& $\mathrm{MnCl}_{2} \cdot 4 \mathrm{H}_{2} \mathrm{O}$ & $0,036 \mathrm{~g}$ \\
\hline Stok Vitamin Primer & $\mathrm{Vitamin}^{2} 1$ & $100 \mathrm{mg}$ \\
& $\mathrm{Vitamin}^{2}$ & $5 \mathrm{mg}$ \\
\hline \multirow{4}{*}{ Stok Trace Metal } & $\mathrm{ZnCl}_{2}$ & $2,1 \mathrm{~g}$ \\
& $\mathrm{CoCl}_{2} \cdot \mathrm{H}_{2} \mathrm{O}$ & $2,0 \mathrm{~g}$ \\
& $\left(\mathrm{NH}_{4}\right)_{6} \mathrm{Mo}_{7} \mathrm{O}_{2} \cdot 4 \mathrm{H}_{2} \mathrm{O}$ & $0,9 \mathrm{~g}$ \\
& $\mathrm{CuSO}_{4} \cdot 5 \mathrm{H}_{2} \mathrm{O}$ & $2,0 \mathrm{~g}$ \\
\hline
\end{tabular}

Tabel 2 .

Komposisi bahan-bahan media Walne bagi pemeliharaan C. gracilis (CPMS II, 1995)

\begin{tabular}{|c|c|}
\hline 01. Tipe uji & Statis, tidak diperbarui \\
\hline 02. Suhu: & $27+1^{\circ} \mathrm{C}$ \\
\hline 03. Intensitas cahaya & $400+40$ foot candles \\
\hline 04 Fotoperiodisasi: & pencahayaan terus menerus \\
\hline 05. Volume botol uji & Erlenmeyer 250-mL \\
\hline 06. Volume larutan uji: & $100 \mathrm{~mL}$ \\
\hline 07. Umur kultur saat inokulasi: & 4-7 hari \\
\hline 08. Kepadatan awal sel: & $10,000 \mathrm{sel} / \mathrm{mL}$ \\
\hline 09. Jumlah ulangan: & 3 \\
\hline 10. Periode homogenisasi & Sehari dua kali dengan tangan \\
\hline 11. Pelarut: & Media pertumbuhan alga tanpa EDTA \\
\hline 12. Faktor pengenceran: & 0.5 \\
\hline 13. Lama uji & 96 jam \\
\hline 14. Efek yang dilihat & Pertumbuhan (jumlah sel) \\
\hline 15. Titik akhir pengamatan & IC50, NOEC and LOEC untuk penghambatan pertumbuhan \\
\hline 16. Kriteria penerimaan uji: & Rata-rata sel dalam kontrol mencapai $2 \times 10^{5} \mathrm{sel} / \mathrm{mL}$ \\
\hline
\end{tabular}

\section{Bioassay terhadap mikroalga}

Kultur murni C. gracilis berumur empat hari diperoleh dari laboratorium Marikultur-Pusat Penelitian Oseanografi LIPI. Satu mililiter larutan kultur C. gracilis dengan kepadatan satu juta sel/ml diinokulasikan ke dalam erlenmeyer berisi $100 \mathrm{ml}$ larutan uji, sehingga kepadatan sel menjadi 10,000 sel/ml. Masing-masing perlakuan memiliki 3 ulangan. Titik akhir pengamatan adalah pertumbuhan (jumlah sel) diatom pada perlakuan lamun dibandingkan dengan kontrol setelah 96 jam yang dihitung dengan haemocytometer. Uji dianggap valid apabila jumlah sel pada kontrol mencapai 2 x $10^{5}$ sel/ml (CPMS-II, 1995, ASTM, 2006).

Nilai persentase penghambatan/inhibition (I) dan stimulasi (S) dari rata-rata jumlah sel tiap perlakuan lamun $(P)$ dibandingkan dengan rata-rata jumlah sel pada kontrol air laut (K) setelah 96 jam pemaparan dihitung berdasarkan persamaan berikut :

$$
\begin{gathered}
\mathrm{K}=\mathrm{K} \\
\mathrm{K}=\frac{\mathrm{P}-\mathrm{K}}{\mathrm{K}} \times 100 \%
\end{gathered}
$$

Parameter kualitas air yang dipantau selama uji adalah oksigen terlarut yang diukur menggunakan DOmeter YSI 55, salinitas menggunakan refraktometer, $\mathrm{pH}$ dan suhu menggunakan $\mathrm{pH}$ meter Eijkelkamp.

\section{HASIL DAN PEMBAHASAN}

Uji toksisitas pertumbuhan mikroalga dianggap valid bila jumlah sel pada kontrol negatif setelah 96 jam adalah $\geq 2 \times 10^{5} \mathrm{sel} / \mathrm{mL}$ (ASTM, 2006). Jumlah 
sel pada masing-masing kontrol pada pengujian kali ini memenuhi persyaratan tersebut sehingga uji dinyatakan valid.

Hasil pengukuran kualitas air untuk uji ekstrak lamun S. isoetifolium dan $C$. serrulata disajikan dalam Tabel 3. Tampak dari Tabel 3 bahwa kualitas air laut selama uji ekstrak adalah baik dan memenuhi kondisi hidup/pertumbuhan diatom C. gracilis.

Uji ekstrak lamun terhadap pertumbuhan mikroalga mengikuti panduan yang direkomendasikan CPMS-II, 1995 dengan modifikasi pada suhu dan salinitas. Modifikasi yang dimaksud adalah kondisi suhu pengujian pada $25^{\circ} \mathrm{C}$ dan salinitas 34 ppt atau mengacu pada kondisi tropis sedangkan panduan yang tercantum dalam CPMS-II, 1995 mengacu pada kondisi subtropis.

Tabel 3.

\section{Pemaparan ekstrak lamun terhadap diatom}

Hasil pemaparan ekstrak lamun terhadap diatom selama 96 jam disajikan pada Gambar 1. Dari gambar tampak bahwa pertambahan jumlah sel diatom yang dipaparkan dengan ekstrak lamun $S$. isoetifolium lebih lambat dari pemaparan C. serrulata. Larutan kontrol pada penelitian ini hanya berisi media pertumbuhan fitoplankton (media Walne) dan kultur C. gracilis tanpa penambahan ekstrak lamun sehingga perbedaan jumlah sel yang terlihat pada Gambar 1 disebabkan oleh variasi individu dari jenis C. gracilis itu sendiri. Variasi antar individu dalam satu spesies/jenis yang sama akan berpengaruh pada sistem metabolisme sehingga rerata jumlah sel yang dihasilkan juga berbeda.

Hasil pengukuran kualitas air laut selama uji ekstrak lamun S. isoetifolium dan C. serrulata terhadap diatom, C. gracilis

\begin{tabular}{llllll}
\hline $\begin{array}{l}\text { Jenis } \\
\text { Lamun }\end{array}$ & $\begin{array}{l}\text { Konsentrasi } \\
(\mu \mathrm{g} / \mathrm{L})\end{array}$ & $\begin{array}{l}\mathrm{DO} \\
(\mathrm{mg} / \mathrm{L})\end{array}$ & $\mathrm{pH}$ & $\begin{array}{l}\text { Temp. } \\
\left({ }^{\circ} \mathrm{C}\right)\end{array}$ & $\begin{array}{l}\text { Salinitas } \\
(\mathrm{ppt})\end{array}$ \\
\hline & Kontrol & 5,88 & 7,94 & 25,7 & 34 \\
& 1 & 5,77 & 8,01 & 25,6 & 34 \\
S. & 10 & 5,84 & 8,10 & 25,3 & 34 \\
Isoetifilum & 100 & 5,88 & 8,14 & 25,4 & 34 \\
& 1000 & 5,95 & 8,14 & 25,5 & 34 \\
\hline & Kontrol & 5,88 & 7,94 & 25,7 & 34 \\
C. & 1 & 5,91 & 8,05 & 25,3 & 34 \\
Serrulata & 10 & 5,89 & 8,08 & 25,4 & 34 \\
& 100 & 5,87 & 8,11 & 25,3 & 34 \\
& 1000 & 5,76 & 8,16 & 25,2 & 34 \\
\hline
\end{tabular}

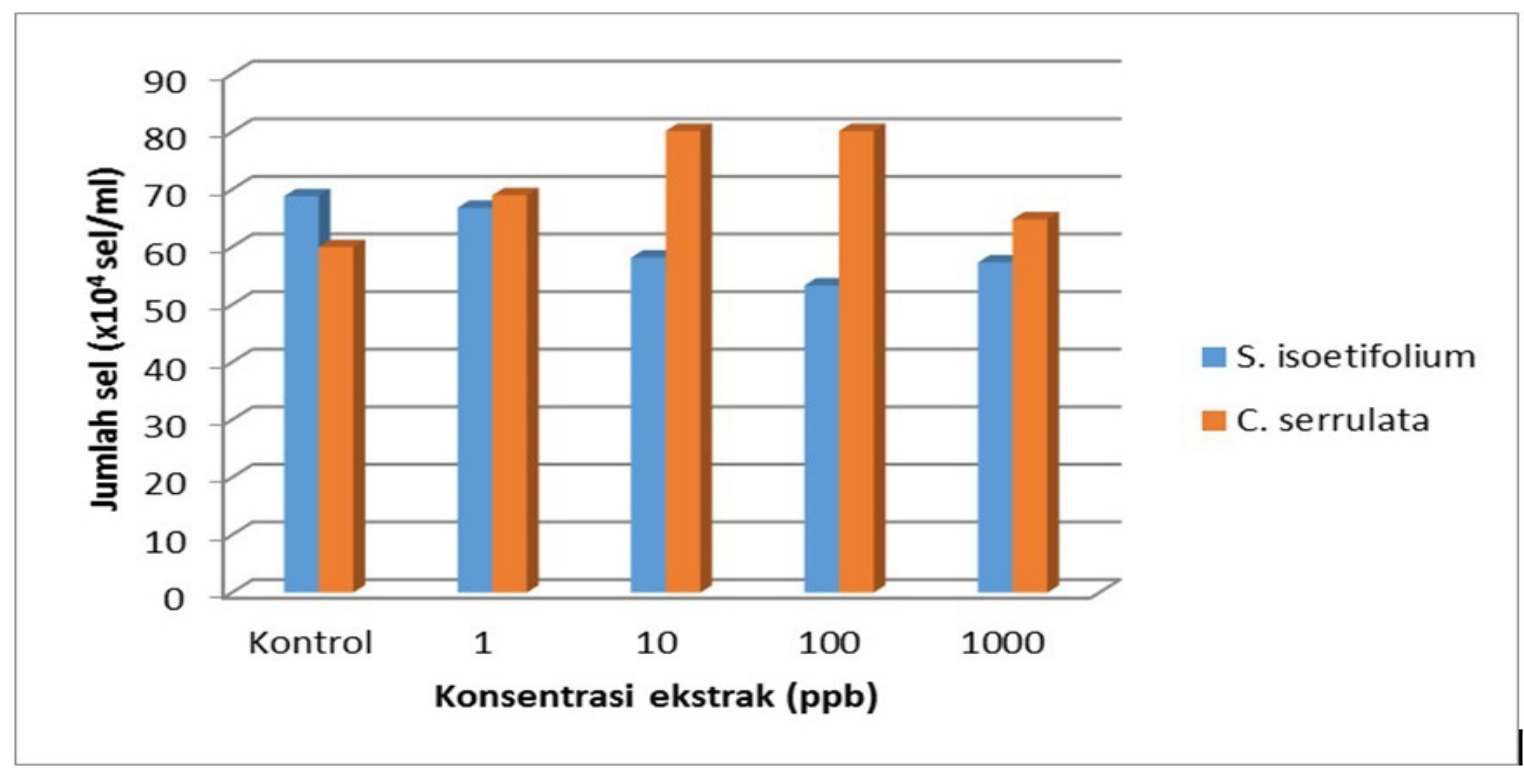

Gambar 1. Rata-rata jumlah sel diatom setelah 96 jam pemaparan dengan ekstrak C. serrulata dan S. isoetifolium. 
Pengaruh berbeda yang terjadi pada pertumbuhan diatom kemungkinan terjadi karena kandungan bahan aktif dari masing-masing ekstrak lamun yang terlarut dalam pelarut polar yaitu metanol. Zat-zat polar yang terkandung dalam lamun hanya larut pada pelarut polar, yaitu air, etanol, metanol dan butanol, sedangkan zat-zat yang nonpolar akan larut dalam pelarut nonpolar, antara lain kloroform, heksan, dan eter (Arlyza, 2008). Metanol merupakan salah satu pelarut yang paling luas digunakan dalam ekstraksi senyawa metabolit sekunder, meskipun metanol merupakan pelarut golongan polar, tetapi metanol dapat mengekstraksi/menarik senyawa-senyawa yang non polar seperti asam-asam lemak, klorofil dan lain.

Perbandingan pemberian ekstrak C. serrulata dan $S$. isoetifolium terhadap stimulasi ataupun penghambatan yang ditunjukkan oleh diatom disajikan berturut-turut pada Gambar 2.

Dari hasil pengujian ekstrak C. serrulata diperoleh bahwa kondisi optimum dimana pemberian ekstrak yang masih menstimulasi pertumbuhan diatom adalah pada 10 dan 100 ppb. Dapat pula dikatakan bahwa pemberian ekstrak C. serrulata konsentrasi 10 ppb sudah cukup untuk menstimulasi pertumbuhan diatom. Sedangkan pada pemberian ekstrak $S$. isoetifolium, penghambatan pertumbuhan optimum terjadi di 100 ppb. Penggunaan senyawa antifouling diharapkan tidak mengganggu kesinambungan populasi fitoplankton, oleh karena itu informasi dasar mengenai konsentrasi optimum dari tiap ekstrak terhadap penghambatan pertumbuhan menjadi penting. Penghambatan pertumbuhan dari ekstrak S. isoetifolium menunjukkan bahwa senyawa aktif yang terkandung dari lamun ini berpotensi mengganggu pertumbuhan diatom. Ekstrak $S$. isoetifolium dilaporkan mengandung senyawa kimia golongan fenol dan alkaloid (Mani et al., 2012a), dan ekstrak Cymodocea rotundata mengandung senyawa kimia golongan alkaloid (Mani et al., 2012b). Uji fitokimia secara kualitatif dari ekstrak methanol terhadap Syringodium isoetifolium menunjukkan aktivitas positif terhadap fitokonstituen seperti saponin, resin, protein, karbohidrat, glikosida, senyawa-senyawa asam, gula tereduksi, fenol dan alkaloid namun negatif terhadap tannin, sterol, dan flavanoid (Mani et al., 2012a). Untuk analisis fitokimia terhadap $C$. serrulata belum ditemukan data penelitian ilmiahnya, namun bila mengacu pada kesamaan genus, maka (Mani et al., 2012b) pernah menganalisis kandungan fitokimia $C$. rotundata dalam ekstrak methanol. C. rotundata positif mengandung fitokonstituen seperti tannin, saponin, resin, protein, senyawa asam, gula tereduksi, terpenoid, dan alkaloid serta negatif terhadap keberadaan fenol, steroid, katakol dan flavanoid.

Robinson (1995) memaparkan senyawa golongan alkaloid potensial dimanfaatkan sebagai antibakteri dan bahan obat obatan analgesik. Senyawa pada golongan alkaloid diduga mampu mengganggu komponen penyusun peptidoglikan, sehingga dinding sel bakteri tidak tersusun dengan utuh, kemudian menyebabkan kematian. Ekstrak yang mengandung senyawa golongan steroid diketahui memiliki potensi sebagai antibakteri dan antifungi, dengan mekanisme merusak membran sel bakteri, sehingga menghambat pertumbuhan bakteri (Dewi et al., 2012). Kemungkinan yang terjadi adalah kedua jenis ekstrak lamun tersebut

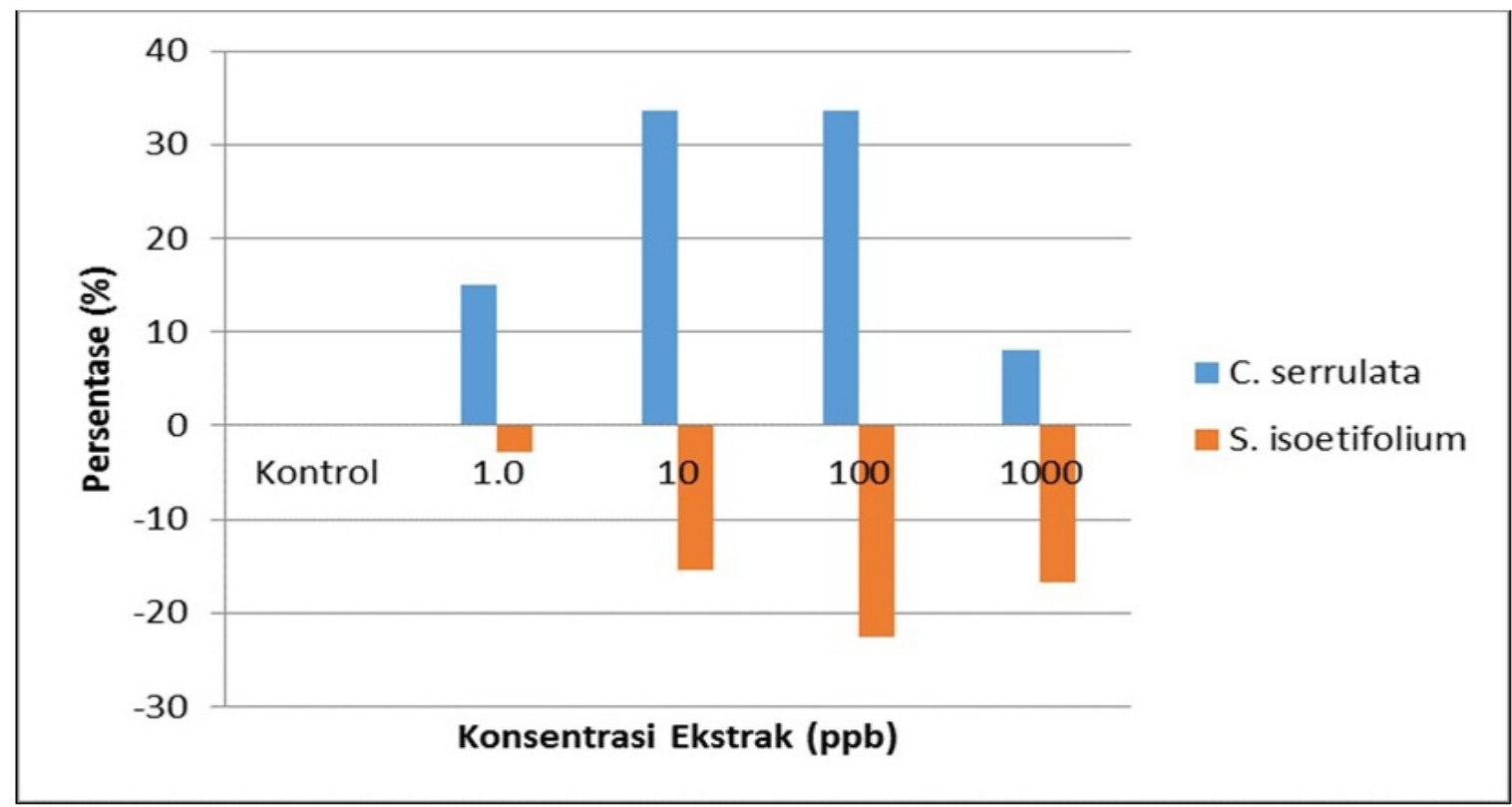

Gambar 2. Stimulasi ekstrak lamun C. serrulata dan S. isoetifolium terhadap pertumbuhan diatom, C. gracilis. Grafik ke bawah menunjukkan penghambatan pertumbuhan dan grafik ke atas menunjukkan stimulasi pertumbuhan. 
mengandung alkaloid yang berbahaya bagi sel organisme dengan kadar yang berbeda. Kandungan bahan aktif alkaloid dalam ekstrak metanol $S$. isoetifolium lebih tinggi daripada $C$. serrulata sehingga ekstrak $S$. isoetifolium cenderung menghambat pembelahan sel diatom dan menurunkan jumlah selnya. Dengan demikian dapat dikatakan bahwa ekstrak C. serrulata lebih aman bagi populasi diatom. Selain itu, hasil penelitian aktivitas uji antibakteri yang dilakukan oleh Arlyza (2008), menunjukkan bahwa $C$. serrulata mampu menghambat bakteri $B$. subtilis dan $V$. harveyii sedangkan $S$. isoetifolium hanya menghambat terhadap $B$. subtilis saja, sehingga $C$. serrulata lebih potensial dikembangkan lebih lanjut sebagai bahan antifouling.

\section{KESIMPULAN}

Hasil bioassay menunjukkan bahwa ekstrak $C$. serrulata lebih aman bagi populasi diatom, C. gracilis dilihat dari adanya aktivitas stimulasi pada konsentrasi optimum ekstrak yaitu 10 dan 100 ppb dalam kondisi laboratorium. Selain itu, informasi sekunder mengenai kemampuan penghambatan terhadap $B$. subtilis dan V. harveyii dapat menguatkan potensi $C$. serrulata sebagai alternatif bahan antifouling yang lebih potensial dibanding S. isoetifolium.

\section{PERSANTUNAN}

Penulis mengucapkan terima kasih kepada Sdr. Arifin dan Sdr. Triyoni Purbonegoro atas bantuannya selama penelitian di laboratorium dan di lapangan.

\section{DAFTAR PUSTAKA}

Arlyza, I. S. (2008). Ekstrak Lamun Sebagai Sumber Alternatif Antibakteri Penghambat Bakteri Pembentuk Biofilm. Oseanologi dan Limnologi di Indonesia. Vol. 34 (2). Hal. 207-225

ASTM. (2006). Standard Guide for Conducting Static 96-h Toxicity Testing with Marine Algae method E 12 18-19 in : Annual Book of Standards. Vol. 11.06 Biological Effects and Environmental Fate; Biotechnology; Water and Environmental Technology. ASTM International, West Conshohocken, PA. pp. 58-78

Bellas, J. (2006). Comparative toxicity of alternative antifouling biocides on embryosan d larvae of marine invertebrates. Science of the Total Environment, 367: pp. 573-585.

Berard, A. (1996). Effect of Organic Four Solvents on Natural Phytoplankton Assemblages: Consequences for Ecotoxicological Experiments on Herbicides". Bull. Environ. Contam. Toxicol.
57: 183-190.

Campanella, L., F. Cubadda, M. P. Sammartino \& A. Saoncella. (2000). An Algal Biosensor for the Monitoring of Water Toxicity in Estuarine Environments. Water Res. 25: 69-76.

CPMS-II. (1995). Draft Protocol for Sub lethal Toxicity Tests Using Tropical Marine Organisms. ASEANCanada Cooperative Programme on Marine Science - Phase II. Regional Workshop on Chronic Toxicity Testing, Burapha University, Institute of Marine Science, Thailand.pp.14-19

Dewi, C. S. U., D, Soedharma. \& M. Kawaroe. (2012). Komponen Fitokimia dan Toksisitas Senyawa Bioaktif dari Lamun Enhalus acoroides dan Thalassia hemprichii dari Pulau Pramuka, DKI Jakarta. Jurnal Teknologi Perikanan dan Kelautan. Vol. 3(1) : 23-28

Hindarti, D. (2008). Uji Toksisitas Sedimen Dengan Diatom Planktonik, Chaetoceros gracilis. Oseanologi dan Limnologi di Indonesia Vol.34 (3) : 461-478.

Panggabean, L. M. G. (1997). Toxicity of Hexavalent Chromium and Cadmium to Green Mussels (Perna viridis) Embryo. Pp X-38-43. In : Vigers, G. A,K.S.Ong, C. McPherson, N. Millson,I. Watson and A. Tang (eds.).ASEAN Marine Environmental Management : Quality Criteria and Monitoring for Aquatic Life and Human Health Protection. Proceedings of the ASEAN - Canada Technical Conference on Marine Science (24-28 June 1996), Penang, Malaysia. EVS Environment Consultants, North Vancouver and Departement of Fisheries Malaysia. p. 817.

Mani A.E, V. Aiyamperumal \& J. Petterson. (2012a). Phytochemical of the seagrass Syringodium isoetifolium and its antibacterial and insecticidal activities. European Journal of Biological Science, Vol. 4(3): $63-67$.

Mani A.E, V. Bharathi \& J. Patterson. (2012b). Antibacterial activity and preliminary phytochemical analysis of seagrass Cymodocea rotundata. International Journal of Microbiological research. Vol. 2(2): 99 - 103.

Robinson T. (1995). Kandungan Organik Tumbuhan Tinggi. Bandung: ITB Press. hal. 191

Sudaryanto, A. 2001. Pencemaran Laut oleh Senyawa Organotin. Jurnal Teknologi Lingkungan, Vol. 2 (3) : 241-246 
Sidharta, B. R. (2000). Sifat-sifat Bakteri Laut; Pengantar Mikrobiologi Kelautan. Yogyakarta. Universitas Atmajaya : hal.1-13

Wang, X., H. Hong, D. Zhao \& L. Hong. (2008). Environmental Behavior of Organotin Compounds in the Coastal Environment of Xiamen, China. Marine Pollution Bulletin 57 : 419-424 
